\title{
Getting Tough on Crime: Will it Win the War?
}

\section{Jenny Williams}

ustralia's rising crime rate remains an issue of considerable public
concern, the significance of which was not lost during the last Federal
election. At the launch of his 'A Safer and Stronger Australia' policy, John Howard proclaimed protecting the community from crime as the first responsibility of government. While placing 'strong and effective law enforcement' at the heart of his 'fight against crime', Howard conceded that the criminal justice system was largely the responsibility of state and local governments.

The emerging trend in policy response from State legislatures has been the passage of bills establishing mandatory minimum sentences for various crimes. Prominent is the Northern Territory's 'one strike' law, passed in November 1996. This law imposes a mandatory prison sentence for first time adult property offenders and applies to many common and less serious offences, including criminal damage, stealing, unlawful entry of a building and unlawful use of a motor vehicle. For adults (17 years of age and over) found guilty of nominated property offences, the first offence attracts a sentence of 14 days imprisonment, the second offence 90 days and the third and subsequent offences 12 months. Mandatory sentencing legislation, imposing a minimum 12 months imprisonment for a third conviction of home burglary, was also introduced in Western Australia (WA) in the same year.

To implement this type of legislation, the courts must be able to incarcerate offenders convicted of crimes covered by mandatory sentences. Walker and Dagger (1993) report that nationally, male prisons are operating at 103 per cent of capacity. The NT has the highest occupancy rate of 118 per cent of capacity. Thus, shortly after introducing the 'one strike' policy, the Northern Territory (NT) Correctional Services Minister announced plans to build a new three million dollar prison to house 140 more prisoners. Over and above these construction costs, incapacitation of criminals is a costly business, estimated to be around $\$ 56,000$ per offender annually (Australian Crime - Facts and Figures, 1998). The expense associated with these 'tough on crime' policies raises the question of the effectiveness of mandatory imprisonment as a response to the growing problem of crime. This paper addresses this question.

Sufficient data are not yet available to assess the long-term impact of the new mandatory sentencing legislation in NT and WA. However, New South Wales (NSW) experience is relevant. Since the abolition of remissions in 1989 ,

Jenny Williams is a Lecturer in the School of Economics at The University of Adelaide. 
sentencing outcomes in NSW have been similar to mandatory sentencing in two important respects. Since 1990, NSW courts have been more likely to impose imprisonment, and the probability of a repeat offender being incarcerated, compared with a first time offender, has increased. Since these policies have been in place for a longer period, we take advantage of the greater information available from NSW to evaluate the impact of tougher sentencing policies on the crime rate.

We begin in the next section by putting the size of Australia's crime problem in an international perspective through comparisons with England and the US. Having established the magnitude of crime in Australia, the next section provides a framework useful for understanding the 'tough on crime' policy approach. Discussion of the NSW experience follows. Multivariate regression analysis is used to examine why the rate of crime has continued to grow in NSW despite the harsher sentencing regime.

\section{The Size of Crime In Australia: An International Perspective}

According to the Australian Bureau of Statistics (ABS) (1997), 159,699 violent offences (comprising 360 homicides, 123,940 assaults, 14,138 sexual assaults and 21,261 robberies) and 1,077,596 property offences (including 417,845 unlawful entry with intent offences, 130,406 motor vehicle thefts and 529,345 other thefts) were reported to police in Australia in 1997. In order to compare the incidence of these crimes in Australia with the US and England, the levels of these offences should be converted to rates per 100,000 persons.

\section{Table 1: A Comparison of Recorded Crime Rates in Australia, England $^{\mathrm{a}}$ and the United States}

\begin{tabular}{|c|c|c|c|}
\hline & \multicolumn{3}{|c|}{ Rate per 100,000 in the population } \\
\hline & Australia & England & US \\
\hline \multicolumn{4}{|l|}{ Property } \\
\hline Unlawful Entry with Intent & 2,196 & 2,240 & 940 \\
\hline Motor Vehicle Theft & 671 & 950 & 530 \\
\hline \multicolumn{4}{|l|}{ Violent Crimes } \\
\hline Homicide & 1.9 & 1.3 & 7.4 \\
\hline Assault & 623 & 440 & 390 \\
\hline Sexual Assault & 79 & 22 & 71 \\
\hline Robbery & 89 & 140 & 200 \\
\hline
\end{tabular}

Sources: Australian Bureau of Statistics (1996); Langan and Farrington (1998).

Note: a. $=$ Data for England include Wales.

Table 1 compares the crime rate per 100,000 in the population for Australia, England and the United States for the year 1996, the latest year for which data are available. The data show that the Australian public concern with crime is 
justified. The rate of recorded crime in Australia is higher than in England or the US for many of the categories under comparison. While its homicide and robbery rates compare favourably with the US, Australia has a much higher rate of assault, breaking and entering (unlawful entry with intent), and motor vehicle theft. Compared with England, Australia has a lower rate of motor vehicle theft and robbery, but higher rates of homicide, assault, and sexual assault.

Recorded crime reflects only those crimes reported to or detected by the police. To verify that the differences in recorded crime across these three countries is due to differences in criminal activity and not in reporting behaviour, Table 2 presents a comparison of crime rates based on national victimisation surveys. The US data are from the National Crime Victimisation Survey and reflect the rate of victim-survey offences for the population aged 12 years and over for the calendar year 1995. The UK data, also for the calendar year 1995, are from the British Crime Survey which covers the population aged 16 years and over. The ABS conducts a nationwide household survey on crime and safety on an infrequent basis. The most recent Crime and Safety Surveys were conducted in 1998 and 1993. The ABS reports that the 1998 victimisation rates are similar to those based on the 1993 survey data. Data from the 1998 survey, which measures rates of victimisation in the population aged fifteen years and over during the 12 month period to April 1998, is contained in Table 2. Notwithstanding differences across countries in reporting criminal behaviour, these data confirm that crime is a serious social problem in Australia, whether it is measured by victimisation survey data or by reported crime statistics.

\section{Table 2: A Comparison of Survey Crime Rates in Australia, England and the USA}

$\begin{array}{ccc}\text { Australia } & \begin{array}{c}\text { Rate per } 1000^{\mathrm{a}} \\ \text { England }\end{array} & \text { USA } \\ 76 & 83 & 48 \\ 17 & 24 & 11 \\ & & \\ 43 & 20 & 9 \\ 5 & 8 & 5\end{array}$

Source: ABS (1999); Langan and Farrington (1998).

Note: $a=$ Households for property crime; persons for violent crime.

\section{Framework for Crime Policy Development}

Underlying the 'get tough on crime' approach is the assumption that criminals are rational in the sense that they engage in crime because they expect that the benefits outweigh the costs. The benefits may be pecuniary, or non-pecuniary. 
Non-pecuniary rewards from crime include the 'rush' from doing something illegal. The costs of engaging in crime include the expected costs associated with being caught and punished, as well as the time cost. The time cost, or opportunity cost of time spent in crime, captures the idea that in order to engage in crime an individual must give up time otherwise spent doing something else. Alternative time uses may be income generating, such as work, or simply leisure. By engaging in crime the offenders incur the cost of forgone benefits associated with the next best use of their time.

This way of viewing crime was first formalised by Becker (1968), and refined by Ehrlich (1973). Ehrlich's model views the decision for optimal allocation of resources, referred to collectively as time, to the activities of leisure, legitimate labour market employment, and crime. Note that this analysis is not confined to income generating crime, applying equally well to crime which generates direct utility to the individual, as does leisure. If all costs and benefits of crime and work are converted to their monetary equivalents, then criminal activity is similar to employment in that it requires time and produces income (Ehrlich, 1973). However, crime differs from employment in at least one important respect. The costs associated with crime are uncertain since they depend on whether the offender is apprehended; with some positive probability the individual will be caught and punished.

\section{Figure 1: Marginal Cost and Benefit of Time in Crime}

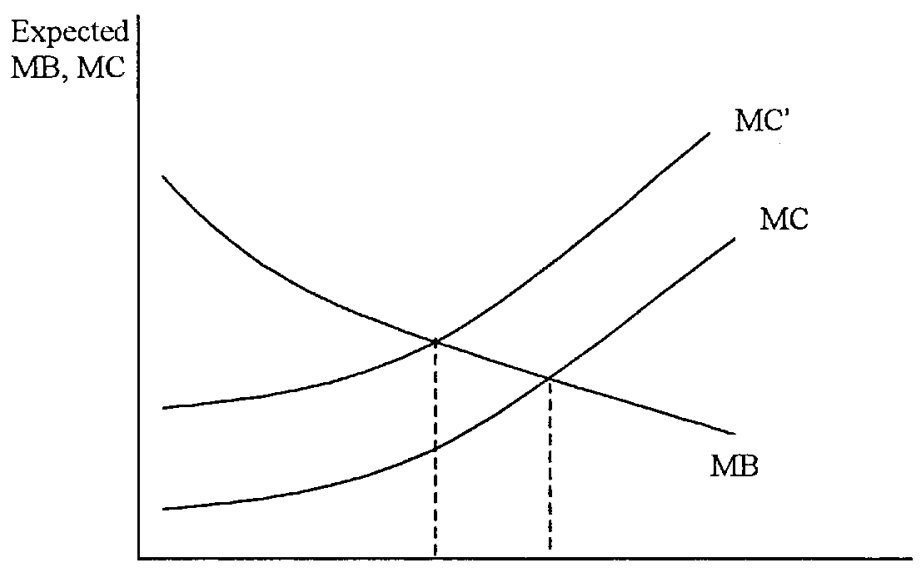

Time in Crime

Drawing on Buchanan and Hartley (1992) an individual's optimal allocation of time to crime decision may be illustrated diagramatically using marginal cost and benefits curves, as shown in Figure 1. The marginal cost of time in crime is upward sloping. This reflects the assumption that each additional hour devoted to crime has a greater opportunity cost in terms of forgone legitimate earnings and leisure. The expected punishment, which is also a cost of engaging in crime, depends on both the probability of apprehension and the size of the punishment. 
The marginal cost of time in crime function can be considered the individual's supply of time in crime.

The marginal benefit of time spent in crime reflects the expected return to criminal activity. It is downward sloping to reflect the fact that criminals will choose to exploit the most rewarding criminal opportunities first. With each subsequent crime, the offender will reap a smaller reward. Also, at higher levels of crime, members of the offender's community are more likely to take actions to protect themselves, called target hardening, further reducing the marginal benefits to crime as crime rises.

Figure 1 illustrates the response of a potential criminal's supply of time to crime to changes in the expected marginal cost of punishment. An increase in either the probability of apprehension or the level of punishment if caught increases the expected marginal cost of time spent in crime. This is represented on Figure 1 by an upward shift from MC to MC'. The increased cost reduces the incentive to participate in crime at the margin, resulting in a reduction in the time the individual allocates to criminal activities.

An important insight from this model of crime is that expected penalties deter marginal criminal acts. The significance of this lies in the fact that even if the expected monetary costs and benefits of committing crime are not the only reason for committing crime, decreases in the benefits or increasing the costs of committing crime can reduce the total number of crimes.

'Get tough on crime' policies such as mandatory sentencing aim to reduce the level of crime by (1) using increased costs of punishment if caught as a deterrent, and (2) by incapacitating convicted criminals. If the penalty for a criminal act is raised through mandatory sentencing policy, then a potential offender must weigh these increased costs against the expected return from the crime. If the rewards are not sufficient to compensate the offender for risking the greater penalty, then the offender will be deterred from committing the crime. The incapacitation effect refers to the fact that, while they are in prison, convicted offenders are prevented from committing crimes against the general public. The deterrence effect is likely to be quantitatively more important than incapacitation in reducing crime. This is because deterrence applies to the whole population - everyone is a potential offender. In contrast, the incapacitation effect applies only to those offenders who are caught and imprisoned.

\section{Getting Tough on Crime in NSW}

Since 1989, NSW has pursued a targeted 'get tough on crime' approach which has seen harsher penalties for repeat offenders and for more serious crimes. The NSW Sentencing Act 1989 abolished remissions and the courts did not compensate for this change in handing down minimum sentences. This effectively increased prison sentences by 25-33 per cent across the board (Matka, 1991; Gorta and Eyland, 1990). Moreover, the legislative change had a wider impact on sentencing in both the Local and Higher Courts in NSW. A recent report by the NSW Bureau of Crime Statistics and Research found that since 1990, NSW courts have been 
more inclined to imprison convicted offenders (Baker, 1998). The Bureau's research also shows that the courts have become much tougher on repeat offenders relative to persons with no prior convictions, and prison sentences for repeat offenders have become much longer.

This tougher policy regime has seen the prison population increase by about 30 per cent to reach a total of 6,325 by 1996 . Taken as a proportion of the population aged 17 years or over, the rate of incarceration increased from 109 per 100,000 to 135 . During the 10 years prior to the abolition of remissions, the number of incarcerated people was growing at an average annual rate of about one per cent. Since then, the incarcerated population has grown by about seven per cent annually. Given this large increase in the number of individuals incarcerated, we would expect that the incapacitation and deterrent effects would have caused the crime rate to fall substantially.

Figure 2 shows that the crime rate did eventually respond modestly to the increased incarceration rates. However, it appears that the effect was temporary. Notwithstanding the continuing increase in the incarceration rate, by 1993, the trend of an increasing crime rate was re-established. This must lead policy makers to ask why people are increasingly turning to crime in the face of increased penalties. Perhaps criminals do not respond to deterrence.

Figure 2: NSW Recorded Crime Rate

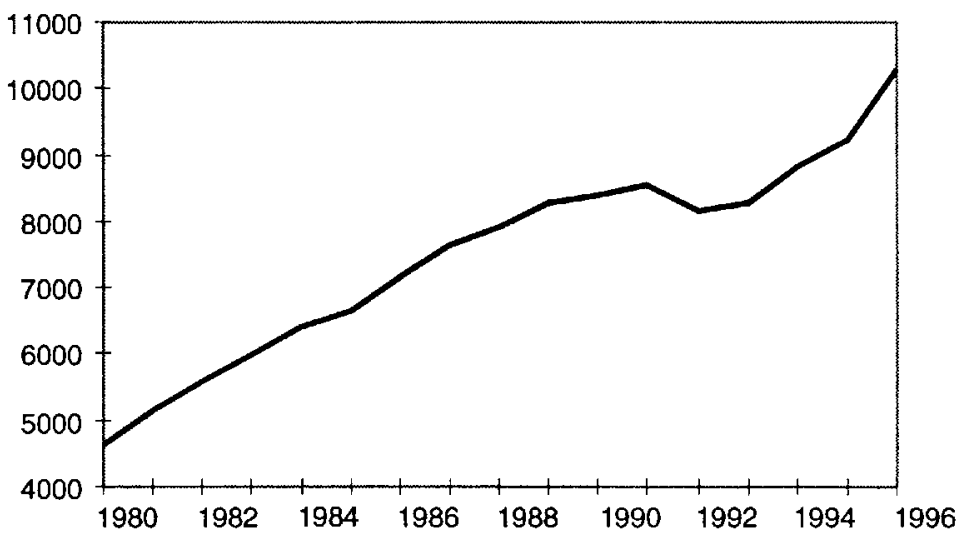

Source: New South Wales Recorded Crime Statistics.

Another possible explanation of why crime has continued to rise in the face of higher penalties is that a countervailing factors may have operated. For example, if the criminal justice budget was not increased when the tougher sentencing regime was introduced, then resources would have to be re-allocated away from catching and convicting criminals to pay for the increased population of 
incarcerated criminals. The reduction in the probability of being charged and convicted would then weaken the deterrent effects of the tougher sentencing regime, which can only be applied once a criminal is convicted. A further possibility is that alternative uses of time, such as employment may have become scarcer. This reduces the opportunity costs of time, making it relatively more worthwhile to the potential offender to engage in crime. We investigate the possibility of these countervailing influences on the crime rate using a linear regression model. This method allows us to separate out the influence of each factor on the crime rate.

\section{Explaining the Rise in Crime}

Based on the benefit-cost framework discussed above, we model the NSW (reported) crime rate as a function of criminal justice policy variables and the opportunity cost of crime. We include the probability of being charged, the probability of being convicted given charged, and the probability of being imprisoned given conviction as the criminal justice deterrence variables explaining the crime rate. We also include the number of police per capita to allow for the fact that increasing the number of police (relative to the size of the population) is likely to increase the number of crimes detected and recorded.

A potential measure of the time cost of crime is forgone earnings. Unfortunately, there is no obvious measure of the legitimate earnings of criminals. The unemployment rate is often used as a proxy for the time cost of crime since the higher the rate of unemployment, the smaller the probability of a potential criminal being able to get a job and obtain legitimate earnings, the smaller the time cost of engaging in crime. However, since those at risk of committing crime are likely to be drawn from young men who have fewer job prospects than the average unemployed person, the model is estimated using the proportion of working age males not in the labour force as the measure of the opportunity cost of crime. This measure reflects men who are working age, but are neither working nor looking for work (according to ABS definitions). Many of these men are discouraged workers who have left the labour force because they believe their employment prospects are so poor. All else being equal, poor employment prospects imply a low opportunity cost of time in crime, and hence a higher rate of crime.

There is much evidence that individuals who are at risk of criminality are also likely to face worse employment prospects than other members of society. The 1992 prison census revealed that 65.8 per cent of prisoners were unemployed at the time of arrest. Only one in eight prisoners had completed secondary school. Indigenous percentages for both unemployment and school completions were far worse than for non-indigenous prisoners with six per cent completing secondary school, and 77 per cent unemployed (Walker and McDonald, 1995). Prisoners are also predominantly male, accounting for 94 per cent of the prison population in 1997.

The following model of the crime rate in NSW was estimated using annual data for the period 1980 to 1996 . Specification tests do not reject the hypotheses 
of homoskedasticity, serially uncorrelated and normally distributed errors. Details of these tests can be obtained on request from the author. Definitions of the variables and data sources are given in the appendix.

$$
\begin{aligned}
& C R_{t}=0.14-0.74 P r \text { Charged }-1.22 \text { PrConviction }-0.43 \text { PrJail }+0.56 N I L F+1.17 \text { Police } \\
& \begin{array}{llllll}
\text { pvalues } & (0.00) & (0.00) & (0.00) & (0.07) & (0.00)
\end{array} \\
& \mathrm{R}^{2}=0.99
\end{aligned}
$$

All variables are measured in logs, so the coefficients are interpreted as elasticities. For example, the coefficient on the probability of being charged is interpreted as follows: a one per cent increase in the probability of being charged decreases the crime rate by 0.74 per cent on average, holding all else constant. These results indicate that each of the deterrence variables has a negative effect on the crime rate, as expected (all explanators are statistically significant at the one per cent level of significance, except the proportion of men not in the labour force, which is significant at the 10 per cent level). These results also imply that a larger pool of men not in the labour force is associated with higher levels of crime. In particular, a one per cent increase in the proportion of working age males not in the labour force is associated with a 0.56 per cent increase in the crime rate. It is common for the unemployment rate to be used to capture the time cost of engaging in crime. Although not reported here, we experimented with specifications which used the unemployment rate. The unemployment rate was found to be positively correlated with the crime rate, but not statistically significant. This is a very common finding in the literature, and may be because the unemployment rate for the general population is not a good proxy for the employment prospects faced by a prospective offender. We also find evidence of a 'net-widening effect' whereby an increase in the number of police per capita is associated with an increase in the recorded crime rate. These results are now used to examine why the crime rate rose in NSW in the face of increased penalties.

The estimated model predicts over the period 1989 to 1996 , the crime rate increased by 23 per cent (this compares with an actual increase of 25 per cent). This increase can be decomposed into the components associated with changes in the probability of being charged $\left(0.74 *\left(\operatorname{PrCharged}_{1996}-\operatorname{PrCharged}_{1989}\right)\right)$, probability of conviction given charged $\left(1.22 *\left(\right.\right.$ PrConviction $_{1996}-$ $\left.\operatorname{PrConviction}_{1989}\right)$ ), probability of imprisonment given conviction $\left(0.43^{*}\left(\right.\right.$ PrJail $_{1996}$ - PrJail $\left.\left.{ }_{1989}\right)\right)$, the number of police per capita, $\left(1.17^{*}\left(\right.\right.$ Police $_{1996}-$ Police $\left.\left._{1989}\right)\right)$, and the proportion of working age males not in the labour force $\left(0.56^{*}\left(N_{1 L F_{1996}}-\right.\right.$ $\left.N I L F_{1989}\right)$ ). The results of this decomposition are given in Table 3. 


\section{Table 3: Decomposing the Predicted Change in the Crime Rate}

Total Change in the Crime Rate

Probability of being Charged

Probability of Conviction

Probability of Imprisonment

Police per capita

Not in Labour Force
23.3 per cent

2.7 per cent

37.2 per cent

-16.1 per cent

-4.5 per cent

3.9 per cent

Table 3 shows that the increased probability of imprisonment did have a crime reducing effect, expected to have decreased the crime rate by 16 per cent, all else being equal. However, other factors changed during this period, reversing the expected fall in the crime rate associated with the greater probability of imprisonment. In particular, both the probability of being charged, and the probability of conviction once charged, fell during this period, reducing the cost of engaging in crime, and hence contributing to the increase in the crime rate. These factors contributed a three per cent and 37 per cent increase in the expected rate of crime, respectively. Further, the reduction in the number of police per capita reduced the number of detected crimes by about five per cent. Taken together, the changes in the criminal justice variables would have been expected to increase the rate of crime by about 20 per cent. In addition, the proportion of working age males not in the labour force also increased during this period. This had the effect of increasing the expected crime rate by four per cent. The combined effect of changes in the criminal justice and labour force variable adds up to the predicted increase in the crime rate of about 23 per cent.

\section{Conclusion}

Crime has emerged as an issue of considerable concern to Australians in recent years. Increasingly, the political response is to turn to mandatory sentencing legislation. Mandatory imprisonment is expensive, both in terms of the capital outlay for providing additional prison places, and in terms of the recurrent costs of housing convicted offenders in prisons. Therefore, unless the law and order and public safety budgets are increased accordingly, these policies will necessitate a reallocation of funds away from agencies which apprehend and convict criminals to pay for the increased rate of incarceration. Ironically, the introduction of 'get tough on crime' policies increases the burden on these other agencies. For example, mandatory sentencing creates an incentive for those who are charged with a crime to plead not guilty, rather than enter a plea bargain. This requires more resources in order to obtain a conviction, since the matter must go to trial.

Although we are unable to obtain expenditure information to consider this aspect directly, published court data reveal that the probability of being charged 
and convicted has fallen markedly since the introduction of a harsher sentencing regime in NSW. Our analysis shows that the effect of the decline in the likelihood of conviction has more than outweighed the crime reducing effects of increased incarceration. The net impact of the changes in the criminal justice system in NSW since 1989 has been to increase the rate of crime. While getting tough on crime may have political resonance, it is yet to win the war on crime in NSW.

\section{References}

Australian Bureau of Statistics (ABS) (1999), Crime and Safety, Australia, Catalogue No. 4509.0, Canberra.

Australian Bureau of Statistics (1997 and 1996), Recorded Crime in Australia, Catalogue No. 4510 , Canberra.

Australian Bureau of Statistics (1998), Corrective Services in Australia, Catalogue No. 4512, Canberra.

Australian Bureau of Statistics (1994 and 1997), New South Wales Year Book, New South Wales Office, Sydney.

Australian Institute of Criminology (1998), Australian Crime: Facts and Figures 1998, Australian Institute of Criminology, Canberra.

Baker, J. (1998), 'Are the Courts Becoming More Lenient? Recent Trends in Convictions and Penalties in NSW Higher and Local Courts', Crime and Justice Bulletin, Bureau of Crime Statistics and Research Publications, Sydney.

Becker, G. (1968),'Crime and Punishment: An Economic Approach,' Journal of Political Economy LXXVI:169-217.

Buchanan, C. and Hartley, P. (1992), Criminal Choice: The Economic Theory of Crime and its Implications for Crime Control, Policy Monograph 24, Centre for Independent Studies, Sydney.

Ehrlich, I. (1973), 'Participation in Illegitimate Activities: A Theoretical and Empirical Investigation,' Journal of Political Economy LXXXI:521-65.

Gorta, A. and S. Eyland (1990), 'Truth in Sentencing: Impact of the Sentencing Act 1989: Report 1', New South Wales Department of Corrective Services, Sydney, (Research Publication, No. 22).

Howard, J. (1998), 'A Safer and Stronger Australia', Transcript of the Prime Minister, the Hon. John Howard MP, Address to Ballajura Community College, Launch of 'A Safer and Stronger Australia' Policy, 16 September. 
Langan, P. and D. Farrington (1998), 'Crime and Justice in the United States and England and Wales, 1981-1996', US Department of Justice, Bureau of Justice Statistics, Washington DC.

Matka, E. (1991), 'NSW Sentencing Act 1989', Legislative Evaluation Series, New South Wales Bureau of Crime Statistics and Research, Sydney.

Mukherjee, S., A. Scadia, D. Dagger, and W. Mathew (1989), Source Book of Australian Criminal and Social Statistics, 1804-1988, Australian Institute of Criminology, Canberra.

Walker, J. and D. Dagger (1993), 'National Corrections Management Information, 1991/92', Australian Institute of Criminology, Canberra.

Walker, J. and D. McDonald (1995), 'The Over-Representation of Indigenous People in Custody in Australia', Australian Institute of Criminology, Canberra (Trends and Issues in the Criminal Justice System, No. 47).

The author gratefully acknowledges financial assistance from the School of Economics Research Grant Fund. This research has benefited from discussions with J. Pincus, David Round, and L. Cameron, and from the comments of two anonymous referees. Special thanks are extended to Bill Jones for excellent research assistance. The usual caveat applies. 


\section{Appendix: Data Sources and Definition of Variables}

\begin{tabular}{|c|c|}
\hline Data & Source \\
\hline Recorded offences & $\begin{array}{l}\text { Source Book of Australian Criminal and Social } \\
\text { Statistics; NSW Recorded Crime Statistics, 1985- } \\
1995\end{array}$ \\
\hline Population & Australian Demographic Trends, ABS 3102 \\
\hline $\begin{array}{l}\text { Total charges brought } \\
\text { before the lower courts }\end{array}$ & $\begin{array}{l}\text { Source Book of Australian Criminal and Social } \\
\text { Statistics; NSW Court Statistics, 1984, 1985, 1986; } \\
\text { NSW Lower Criminal Courts and Children's Courts } \\
\text { statistics, 1989; NSW Criminal Court Statistics, } \\
1991-1996\end{array}$ \\
\hline $\begin{array}{l}\text { Total charges brought } \\
\text { before the higher courts }\end{array}$ & $\begin{array}{l}\text { Source Book of Australian Criminal and Social } \\
\text { Statistics; NSW Higher Criminal Court Statistics } \\
\text { 1988, 1989, 1990; NSW Criminal Court Statistics, } \\
\text { 1991-1996 }\end{array}$ \\
\hline $\begin{array}{l}\text { Total number of } \\
\text { convictions in the lower } \\
\text { courts }\end{array}$ & $\begin{array}{l}\text { Source Book of Australian Criminal and Social } \\
\text { Statistics; NSW Court Statistics, 1984, 1985, 1986; } \\
\text { NSW Lower Criminal Courts and Children’s Courts } \\
\text { Statistics, 1989; NSW Criminal Court Statistics, } \\
\text { 1991-1996 }\end{array}$ \\
\hline $\begin{array}{l}\text { Total number of } \\
\text { convictions in the higher } \\
\text { courts }\end{array}$ & $\begin{array}{l}\text { Source Book of Australian Criminal and Social } \\
\text { Statistics; NSW Higher Criminal Court Statistics } \\
\text { 1988, 1989, 1990; NSW Criminal Court Statistics, } \\
\text { 1991-1996 }\end{array}$ \\
\hline Total number of prisoners & $\begin{array}{l}\text { Source Book of Australian Criminal and Social } \\
\text { Statistics; Australian Prison Trends, 1988-1993; } \\
\text { New South Wales Year Books 1994-1997 }\end{array}$ \\
\hline Male participation rate & Labour Force Australia ABS 6204 \\
\hline
\end{tabular}




\begin{tabular}{|c|c|c|}
\hline \multicolumn{2}{|r|}{ Variable } & Definition \\
\hline $\mathrm{CR}$ & crime rate & $\begin{array}{l}100,000 \times \text { (all recorded offences } \\
\text { population) }\end{array}$ \\
\hline PrCharged & $\begin{array}{l}\text { probability of being } \\
\text { charged }\end{array}$ & $\begin{array}{l}\text { total charges brought before the lower } \\
\text { and higher courts; all recorded } \\
\text { offences }\end{array}$ \\
\hline PrConviction & $\begin{array}{l}\text { probability of } \\
\text { conviction given } \\
\text { charged }\end{array}$ & $\begin{array}{l}\text { total convictions in the lower and } \\
\text { upper courts; total charges brought } \\
\text { before the lower and higher courts }\end{array}$ \\
\hline PrJail & $\begin{array}{l}\text { probability of } \\
\text { imprisonment given } \\
\text { conviction }\end{array}$ & $\begin{array}{l}\text { total number of sentenced prisoners; } \\
\text { total convictions in the lower and } \\
\text { upper courts }\end{array}$ \\
\hline Police & police per capita & total number of police/population \\
\hline NILF & $\begin{array}{l}\text { proportion of working } \\
\text { age men not in the } \\
\text { labour force }\end{array}$ & 100-male participation rate \\
\hline
\end{tabular}

